\title{
Heritage Language Maintenance among Native English Speakers Living in Israel
}

\author{
Orly Kayam $\mathrm{PhD}$ \\ Wingate Academic College \\ Netanya, Israel \\ Accepted: Sep 03, 2013 Published: October 24, 2013 \\ Doi:10.5296/jsr.v4i2.4446 URL: http://dx.doi.org/10.5296/jsr.v4i2.4446
}

\begin{abstract}
Heritage language maintenance research most often focuses on heritage languages in English dominant societies. This paper presents a case-study, the second in a series, which focuses on the family language policy experiences, strategies, and outcomes of native English speakers raising children in a Hebrew dominant environment in Israel.
\end{abstract}

Key Words: Bilingualism, Heritage Language Maintenance, Family Language Policy, Sociolinguistics

Introduction

This case study is part of a series of articles examining the issue of Heritage Language (HL) maintenance in the English speaking community residing in Israel. In our previous study (Kayam and Hirsch, 2013) we examined the Family Language Policy (FLP) of a family where the mother's mother tongue was English and the father's Hebrew. In this current study we examined a family where both the mother and father are native English speakers raised in the United States who moved to Israel in 1977 and 1981 respectively. Both parents are American citizens so the issue of FLP can not be divorced from the broader issue of immigrant integration and acculturation. Michal Tannenbaum's 2003 article in the International Journal of Bilingual Education and Bilingualism "The Multifaceted Aspects of Language Maintenance: A New Measure for its Assessment in Immigrant Families" addressed these issues and reflected the feelings and attitudes expressed by our case study participants: "Immigrants often feel that speaking another language is almost like being someone else, alienated from one's familiar way of thinking and feeling" and "The mother tongue has to do with an internal sense of self, with childhood memories, with relationships with one's own parents, and with emotions associated with the home country and the past" (Tannenbaum, 2003). More recently, Costica Bradatan wrote: "Language is above all a mode of subjective existence and a way of experiencing the world" ("Born again in a second language" International Herald Tribune August 12, 2013). In this article we will show how speaking English is experienced by two generations in an English speaking home located 
within a Hebrew speaking society.

Theoretical background

For the past ten years, Family Language Policy has raised considerable interest and curiosity among linguists and sociolinguists in countries where the presence of ethnic minority groups live. Indeed, in a research paper carried out in the United States by Ha Lam (2011) on Raising Children bilingually in Mixed Marriages[...] it is mentioned the fact that "there are an increasing number of studies on family language policy at microlevel”. In the same way, Mila Schwartz (2010), in her research paper on FLP considers this subject of study as an "[...] emerging field".

This strong interest in FLP which has been put forward in recent studies has been stirred by the presence of populations of various ethnic origins in a given place. Indeed, the increasing rate of immigration in a number of countries as is the case in the UK for example also explains this phenomenon. As is pointed out in Andrea Donakey's 2007 paper entitled: "Language Planning and Policy In Manchester": "this is leading to a rise in metropolitan multilingualism with more and more people in urban localities using languages other than English, or "community languages"”.

The purpose of FLP is to examine and analyze language practices through "various management techniques" (Spolsky, 2004). As mentioned in a paper by Xiao Lan Curdt-Christiansen, Associate Professor in the Department of English Language and Literature, National Institute of Education (NIE), Nanyang Technological University, Singapore, FLP "interacts with a wide range of socio-historical, political, cultural and linguistic variables and factors (Spolsky 2012; King and Fogle 2013). As such, the study of FLP not only contributes to our understanding of the processes of language shift and change, it also sheds lights on broader language policy issues at societal levels."

Method

First the participants were asked to fill out an online questionnaire relating to their language usage. Later face-to-face interviews were conducted with each of the participants individually. The participants were allowed to speak freely on any aspect of heritage language maintenance and family language policy that interested them. They were also asked directly to address their feeling towards speaking Hebrew (the parents) and speaking English (the children).

\section{The Participants}

The family interviewed for this study consists of four members: The mother Carol, who was born and raised in the USA, the father David, who was born in Canada and moved to the States as a young child, and their two daughters, Noga and Ella who were both born in Israel 


\section{Macrothink}

but have dual citizenship. All the names have been changed to protect the privacy of the participants.

The Mother

Carol was born to first generation American parents who were themselves functionally bilingual but the second language was Yiddish and as adults Carol's parents only spoke in Yiddish when they did not want their children to understand what they were saying. Carol started to learn Hebrew at age 8 and when she graduated from Hebrew Day School at age 17 she moved to Israel for 18 months, returning to the States for higher education and immigrating to Israel in 1977 at the age of 24. After 36 years in Israel Carol still prefers to speak, read and write in English.

The Father

David was born to first generation Canadians. His parents and he relocated to the States due to his father's work. David came to Israel in 1981 as a tourist with no definite long term plans. He spent his first year in Israel as a volunteer on kibbutz and studied Hebrew there. In 1982 he changed his status, moved to the city and got a job as a software engineer. Like his wife, David is fluent in Hebrew but prefers to speak, read and write in English.

The older daughter

Noga was born in 1988 and is currently working as a computer programmer while completing her studies at university. She speaks English exclusively with her parents, grandfather, and with her parents' friends. She speaks English with her sister when they are together with their parents but will often switch to Hebrew if they are on their own. Outside of her parents' home she conducts her life primarily in Hebrew though she uses English at work and enjoys reading English books and watching American TV shows.

The younger daughter

Ella was born in 1992 and has just completed her compulsory army service and is currently looking for work. Like her sister she speaks English exclusively within the family but unlike her sister she also has English speaking friends with whom she converses in English. She prefers reading English books and watching American TV shows.

Findings

Motivations, strategies and reflections

Mother 


\section{Mll Macrothink}

Journal of Sociological Research

ISSN 1948-5468

2013, Vol. 4, No.2

Carol had several very strong reasons for wanting her children to be English speakers and it was difficult for her to say which was most important but if forced to pick her number one reason it would be: Being able to communicate with the grandparents. She was influenced in part by the experience of seeing her older brother, who married a native Israeli, had children in the 1970s and chose to raise his children monolingual Hebrew. His reasoning was that he suffered from dyslexia and he was afraid that having two languages in the home would confuse his children. His wife is herself trilingual having lived in both France and the United States. His children had a French speaking babysitter so in any event they were exposed to two languages. Carol witnessed the frustration of the grandchildren and grandparents when trying to communicate with each other and promised herself that her children would know English. Carol also wanted her children to be able to communicate freely with her husband's large extended family abroad. Carol's brother and family relocated to the States when their children were ages 6 and 10 and the older child had to be placed in an English second language (ESL) program, an experience that also impacted on Carol's desire to raise her children bilingual.

The second and equally strong reason for speaking English to her children was that it would have been unnatural not to. Carol is extremely articulate and language is very important to her sense of self and while she is fluent in Hebrew her Hebrew is on a much lower level than her English.

The third reason not to speak Hebrew with her children is that even after all these years in Israel she makes mistakes in word order and masculine/feminine when speaking Hebrew and her vocabulary is much more extensive in English. Also she speaks Hebrew with a pronounced American accent.

In short, Carol never considered speaking to her children in Hebrew. Hebrew was the language of the host country and used for work and interaction with the outside world. English was the language of family and friends.

Father

David's FLP was adopted as a result of the year he spent on a kibbutz in Israel. There he saw bilingual and even trilingual families raising children where the parents would speak to the children at home in the parents' native tongue and the children attended the kibbutz day care from a very young age where the environment was exclusively in Hebrew. He was also aware of anecdotal evidence that children raised in a non-Hebrew environment at home were fully bilingual with native accents in both Hebrew and the home language.

His attitude toward speaking a second language at home was also affected by his brother-in-law. Carol's brother lived in Israel and was married to an Israeli with two children when David met them. The brother-in-law had made a conscious decision to speak to his children in Hebrew so they wouldn't get confused. After seeing a 3 year old on kibbutz who 
could switch between Hebrew, English and French without hesitation, he did not buy into the idea that kids could get confused with language.

David doesn't remember ever discussing the topic of the language in the house. His and Carol's language was English and would remain so. And while he doesn't ever remembering making a decision, he was always consciously aware of a firm belief that raising children bilingual was good for them. He remembers in the intervening years reading newspaper stories about the benefits of being bilingual from birth.

When Noga was born, Carol worked from home and took care of her. Generally Noga's babysitters were either Carol's parents who lived nearby or English speaking neighbors. As a result, Noga rarely heard Hebrew and was never spoken to in Hebrew so she was completely monolingual until age 2. At that point Carol had found work outside the home and some sort of day care was required. David was working from the house during that period and had flexibility in his schedule. David and Carol decided to enroll Noga in day care at a nearby kibbutz.

David would take Noga to the kibbutz and for the first days, would spend several hours there. The whole situation seemed a bit bewildering and stressful to her so he didn't feel comfortable leaving a crying child. After about a week he was able to drop her off and say goodbye. Within a couple months she was functioning well in the Hebrew day care environment.

From what David sees and believes, Noga is a fully functional native Hebrew speaker and he is well aware she speaks, reads and writes Hebrew at a much higher level than English. Still he is quite proud of her ability to speak what he considers to be accentless American English fluently and at a high level.

Ella's early years were quite different. When Carol returned to work after her maternity leave Ella was left in the care of a young Orthodox Jewish woman who lived with her family in the neighborhood and would take Ella home to her family. So Ella was in two purely monolingual environments. David also considers Ella to be completely bilingual and is pleased with her ability to express herself in English. He marvels at her ability to speak very fast to the point of having difficulty comprehending her. He sees this as a personality trait and not anything to do with being bilingual other than the fact she can do it in two languages.

When David moved to Israel and started learning Hebrew on the kibbutz, he made a concerted effort to learn to speak Hebrew and was determined to use it. He would make a point of speaking Hebrew to native Hebrew or Russian speakers, even when he was asked to speak English instead. He always conversed with native English speakers in English. He did continue to speak English to native Israelis with whom he had spoken English before learning Hebrew. 
After about five years in Israel, David felt comfortable speaking Hebrew. In the late 80 's, he made a presentation of a paper he had written for a software engineering conference. He asked the session moderator if he should present in Hebrew or English and was told that Hebrew was preferable which is what he had assumed anyway.

He presented his paper in front of an audience of more than 100 people immediately following a young American woman had made her presentation in English. She had tremendous difficulty speaking in front of a group and it showed. When he made his presentation, he spoke smoothly as was his style in front of groups. He still sees this experience as some kind of watershed event in his transition to being part of the local environment. He always had good work friendships that were maintained entirely in Hebrew but as is typical in these situations, few of these friendships survived transitions to other jobs. The sole exceptions were the friendships with other English speakers.

Today, after 32 years in Hebrew speaking work environments, he feels perfectly comfortable discussing any topic, be it professional or personal in Hebrew. There are times when he finds he is having difficulty expressing complex inner ideas or feelings in Hebrew but he realizes that at times when he tries to express the same things in English, it is a problem of putting these concepts into any words and not a specific language issue.

When he is very tired, he finds it difficult to speak Hebrew and the syntax and accent deteriorate noticeably.

David rarely writes in Hebrew. Only the occasional email for work or personal business. He sometimes reads Hebrew but never anything longer than a newspaper article. He admits he doesn't have the discipline to stick with it until it gets easier. In one of his early jobs, he was required to write software documentation in Hebrew so he is fairly adept at typing in Hebrew.

All told he feels he functions very well in a native Hebrew environment but always prefers to interact in English when he can. Speaking Hebrew is not a great effort but there is always some part of his brain listening and aware of his speaking, syntax, grammar, idioms and accent that he feels makes it more demanding than speaking in English.

Noga

Noga feels equally comfortable conversing in English or Hebrew but is more comfortable writing in Hebrew. She uses English at work, mostly for writing emails, reading professional material and speaking with English speaking colleagues and customers. She is very proud of her English proficiency and says: "I get a lot of compliments on my accent and I like to show off. My boss occasionally uses me as a copywriter when he needs something in English. I am the only native English speaker on my team and occasionally we have to produce customer facing material. I am very grateful that my parents gave me the gift of English. I don't see myself as an American, my parents are American, I am a native English speaker. English for me is a skill not a culture. I think in the world today English is a must have skill and I see the 
people around me struggling, even when they are pretty fluent, they struggle with their accent and their confidence and they have to work really hard their whole life to achieve proficiency." Noga feels very strongly about the importance of knowing English at native speaker level, this is a purely functional approach to the language. She expressed no views on the benefits of bilingualism per se, in fact stating explicitly: "I don't think I would feel so strongly about any other language."

She intends to raise her children bilingual.

Ella

While Ella is totally bilingual she feels that her Hebrew is not as good as her peers who were raised in a Hebrew only home. She feels that knowing England as a native speaker is a great advantage but remembers when it had its drawbacks: "When I was in regular English classes I was bored and I did not speak grammatically correct English, rather I knew what sounded right, but what sounds right to a native English speaker isn't necessarily correct according to the teacher who wasn't a native English speaker. For example, my teacher insisted that a dog be referred to as "it" but a native English speaker would never refer to a dog as "it" but as "he" or "she" depending on the sex of the animal." In high school Ella's teacher was a native English speaker and in addition to the regular English classes Ella attended a supplementary weekly after school class for native English speakers, taught by the same teacher, which enabled her to take her English matriculation exam a year early. (Noga did not avail herself of this option because she did not want to stay after school.)

In contrast to her sister, Ella most definitely feels that English is not just a skill: "The fact that I was brought up in English because my parents were from the States meant that both the culture and the language that I acquired from them was one, meaning English was part of my culture. Sometimes I feel that I am culturally different from other native Israelis, for example, I grew up on English baby songs and videos instead of Hebrew songs and shows. I see myself as an American and an Israeli and this is reflected in American cultural norms like waiting in line and arriving places on time." While Ella sees herself as both an American and an Israeli she feels her Israeli identity is stronger because she lives in Israel and is Jewish and Israeli culture is intertwined with Jewish culture.

Regarding any future children Ella says: "In my ideal fairytale future my partner is a native English speaker (preferably American born so my children will have American citizenship) and my children would be brought up as I was, speaking English at home and Hebrew outside the home. In the event that my partner is not a native English speaker I hope to be able to raise my children in a bilingual home. And I am counting on my parents contributing to my children's English education." 
Discussion

FLP planning in the Weiss household was simplified by both parents' personal preference for speaking English. While both were bilingual, Hebrew was always the language of the outside world, used in the workplace and in dealing with public institutions (the bank, the post office, etc.) while English was always the language they spoke with each other. Therefore raising their daughters in an English speaking home was the natural course to follow.

In the case of their firstborn, Noga, additional steps were taken to strengthen her English language acquisition including hiring a British babysitter and using grandparents as babysitters whenever possible. In fact, for the first two years of her life Noga heard Hebrew only when she was outside the home and she spoke only English. At the age of two she started to attend a local daycare facility and was soon bilingual.

When Ella was born four years later the situation was different. From the age of five months Ella was in the care of a Hebrew speaker several times a week while Carol was at work and of course Ella had a bilingual older sister. As often happens, the older sister started speaking to her little sister in Hebrew. When Carol heard Noga speaking to Ella in Hebrew she had the following conversation with her:

"I explained to Noga that she (Noga) was brought up hearing only English in the home and that was why she could speak English so well. I appealed to her sense of fairness saying that it wouldn't be fair to Ella if she spoke to her in Hebrew and that I wanted her to speak only English with her sister so that Ella would also grow up speaking English well. Noga accepted this reasoning and the girls spoke only English to each other, at least when I was around."

Today the girls are in their twenties and converse in Hebrew when they are alone with each other and in English when they are with their parents or other family members.

Though Noga has a Hebrew speaking partner and their language of communication is Hebrew she says she will raise her future children in English as she feels that English is a very important skill. Her partner will speak to the children in Hebrew. She is counting on her parents to help reinforce their exposure to English.

As for Ella's future partner and children, Ella would like to raise her children in an English speaking home but if her partner is not a native English speaker she plans on raising them bilingual. She is also counting on her parents to help reinforce their exposure to English.

None of the participants expressed interest in sending their children to English or bilingual educational frameworks though all said there should be special classes for native English speakers in lieu of sitting with non-English speakers for English classes. 
References:

Baker, C. (1995). A parents' and teachers guide to bilingualism. Clevendon, UK: Multilingual Matters

Bayley, Robert \& Schecter, Sandra R. 2003. Introduction: Toward a dynamic model of language socialization. In Bayley \& Schecter (eds.), pp. 1-6.

Bradatan, C. (2013). "Born Again in a Second Language". International Herald Tribune, August 12, 2013.

Burns, Allan F. 1984. Join the circle: The folklore of Florida's children. In First citizens and other Florida folks: Essays on Florida folklife. Tallahassee: Bureau of Florida Folklife Programs, Division of Archives. Florida Department of State.

Cardozo-Freeman, Inez. 1975. Games Mexican girls play. Journal of American Folklore 88 (347), pp. 12-23.

Cho, G., \& Krashen, S. (2000). The role of voluntary factors in heritage language development: How speakers can develop the heritage language on their own. ITL: Review of Applied Linguistics, 127-140.

Ben-Rafael, E., Shohamy, E., Amar, M.H., \& Trumpet-Hecht, N. (2004). Linguistic landscape and multiculturalism: A Jewish-Arab comparative study. Tel Aviv: Tami Steinmetz Center for Peace Research.

Crystal, D. (2003). English as a global language. Cambridge University Press.

Cummins, J. (1991). Language Development and Academic Learning. In L. Malavé \& G. Duquett (Eds.), Language, culture, and cognition (pp. 161-175). Clevedon, UK: Multilingual Matters Ltd.

De Capua, A., \& Wintergerst, A. C. (2009). "Second-Generation Language Maintenance and Identity: A Case Study”. Bilingual Research Journal. 32:1, 5-24.

De Houwer, A. (2000). Children's linguistic environments: a first impression. In M. Beers, B. van den Bogaerde, G. Bol, J. de Jong, \& C. Rooijmans (Eds.), From Sound to Sentence. Studies on First language acquisition (pp. 57-68). Groningen: Centre for language and cognition.

de la Piedra, María \& Romo, Harriet D. 2003. Collaborative literacy in a Mexican immigrant household: The role of sibling mediators in the socialization of pre-school learners. In Bayley \& Schecter (eds.), pp. 44-61.

Döpke, S. (1992). One parent one language: An interactional approach. Philadelphia: John Benjamins.

Donakey, A. (2007). Language Planning and Policy in Manchester. A dissertation submitted to the University of Manchester for the degree of Master of Arts in the Faculty of Humanities, School of Languages, Linguistics and Cultures.

English Curriculum, (2001). Israel Ministry of Education.

Garett, P., Coupland, N., \& Williams, A. (2003). Investigating language attitudes: Social Meanings of dialect, ethnicity and performance. Cardiff, UK: University of Wales Press.

Hakuta, K., \& d' Andrea, D. (1992). "Some properties of bilingual maintenance and loss in Mexican background high school students". Applied Linguistics, 13, 72-99.

Hoff, E. (2006). "How social contexts support and shape language development". 
Developmental Review, 26, 55-88.

Kayam, O., Hirsch, T. (2013). “Israel's English Speaking Immigrant Parents' Family Language Policy Management: Language in the Education Domain. International Journal of Linguistics, 5(1) pp. 320-331.

Kayam, O., Hirsch, T. (2012). "Israel's English Speaking Immigrant Parents' Family Language Policy Management: Language in the Education Domain”. International Journal of Linguistics, vol. 4(4), pp. 622-635.

Kayam, O., Hirsch T. (2012). "Family Language Policy of the English Speaking Immigrant Community in Israel: Families with Young Children and their FLP Planning and Management". International Journal of Linguistics (accepted for publication).

Kayam, O., Hirsch, T. (2012). "Using Social Media Networks to Conduct Questionnaire Based Research in Social Studies Case Study: Family Language Policy”. JSR- Journal of Sociological Research, Vol. 3, Issue 2, pp 57-67.

Kayam, O., Hirsch, T., Galily, Y. (2012). "Linguistic Landscape: Investigation of Linguistic Representations of Cape Town". International Journal of Linguistics. 4:3, 71-77.

Lam, H. (2011). "Raising Children bilingually in Mixed Marriages: Stories of Four Vietnamese-Caucasian Families". ProQuest Dissertations and Theses.

Landry, R., \& Bourhis, R.Y. (1997). "Linguistic landscape and ethnolinguistic vitality: An empirical study". Journal of Language and Social Psychology, 16:1, 23-49.

Paradis, J. (2010). Bilingual Children's Acquisition of English Verb Morphology: Effects of Language Exposure, Structure Complexity, and Task Type. Language Learning, 60/3: 651-680.

Portes, A., \& Hao, L. (2002). "The price of uniformity: Language, family, and personality adjustment in the immigrant second generation". Ethnic and Racial Studies, 25, 889-912.

Schecter, S.R., Sharaken-Taboada, D., \& Bayley, R. (1996). Bilingual by choice: Latino parents' rationales and strategies for raising children with two languages. Bilingual Research Journal, 20/2: 261-281.

Schieffelin, B. B. \& Ochs, E. (1986). Language socialization. Annual Review of Anthropology 15.

Schwartz, M. (2010). "Family Language Policy: Core Issues of an Emerging Field". Applied Linguistics Review. Vol. 1, 171-192, ISSN (Online) May 2010.

Tannenbaum, M. (2003). "The Multifaceted Aspects of Language Maintenance: A new measure for its assessment in immigrant families". International Journal of Bilingual Education 6: 374-393.

Toman, W. (1993). Family Constellation: its effects on personality and social behavior. Springer Publishing Company. 